\title{
Preservative Treatment of Keora (Sonneratia Apetala) Poles by Full Cell Method of Wood Preservation with CCA Preservative
}

\author{
M. S. Islam ${ }^{a}$, M. Ashaduzzamana ${ }^{a}$ M. N. Islam ${ }^{a} *$, M. R. Karimb and M. O. Hannana \\ ${ }^{a}$ Forestry and Wood Technology Discipline, Khulna University, Khulna - 9208 and ${ }^{b}$ Department of Chemistry, \\ Chittagong University of Engineering and Technology (CUET), Chittagong, Bangladesh
}

\begin{abstract}
Keora (Sonneratia apetala Buch. Ham.) poles which contain mostly sapwood (more that $61 \%$ ) and are readily susceptible to wood destroying agents were used in the study. Keora poles were treated with 5.5\% CCA-C type preservative by full cell method of wood preservation for the period of 2, 3, 4 and 5 hours with the treating pressure of 200 psi $(1,379 \mathrm{kPa})$. The maximum penetration was $4.36 \mathrm{~cm}$ for 5 hours treating duration. Retention and penetration increased with the increase of treating duration. The total retentions of CCA preservative were $9.15 \mathrm{~kg} \mathrm{~m}^{-3}$ for 2 hours, $12.72 \mathrm{~kg} \mathrm{~m}^{-3}$ for 3 hours, $16.35 \mathrm{~kg} \mathrm{~m}^{-3}$ for 4 hours and $18.31 \mathrm{~kg} \mathrm{~m}^{-3}$ for 5 hours treating duration for sapwood dominated keora poles. Significant variation in penetration and retention was found in the statistical analysis for different treating durations.
\end{abstract}

Key words: CCA-C preservative, Full-cell method, Penetration, Retention, Sonneratia apetala

\section{Introduction}

The Sundarbans is the largest mangrove forest in the world with an area of 401,600 ha (Siddiqi, 2001) and comprise about $4 \%$ of the total land area of Bangladesh (Khaleque and Hannan, 1993). Among the several timber yielding mangrove species in the Sundarbans, keora (Sonneratia apetala Buch. Hum.) is one of the pioneer and fast growing species (Lahiry, 2001). In coastal afforestation, about 0.17 million hectares of the coastal lands were planted with mangrove species (Siddiqi, 1999) of which 95\% were keora (Siddiqi and Shahjalal, 1997). But the species is very susceptible to attack by insect-pests and fungi (Baksha and Islam, 1999). Bangladesh has a large stock of keora timber which remains useless because of its less durability and insect infestation. Untreated sapwood is more susceptible to decay fungi, termite and powder post beetle attack (Tamblyn, 1984), even after drying. Keora is a medium density wood having moderately strong timber but not durable (Sattar and Bhattacharjee, 1983).Traditionally, the species is used as fuel wood, furniture making and boat building (Lakshmanan et al., 1984; Das and Siddiqi, 1985; Haque et al., 1999). However, it can be used for making packing boxes, paneling and other purposes.

CCA treated timbers are being used successfully in ground contact in the USA since 1938 (Lahiry, 2001). The effective treatment of wood poles with CCA depends on penetration, retention and degree of fixation of CCA in wood. Poor microdistribution in hardwood poles may be overcome by using higher retention of around $20 \mathrm{~kg} \mathrm{~m}^{-3}$ or $4 \% \mathrm{w} / \mathrm{w}$ dry oxide of CCA (Leightley, 1987) and give effective retention for hardwood species (Lahiry, 2001). Arsenic containing CCA-C type preservative has been used as the most fixative type of water borne preservative. In general, the treated sapwood gives a pole, as a whole, an increased service life by 3 to 4 times (Latif et al., 1981; 1982).

Rural Electrification Board (REB) of Bangladesh needs huge amount of log for wooden poles, anchor logs and crossarms. About 250,000 poles, 100,000 anchor logs and 100,000 cross-arms are the annual requirements of REB (Lahiry, 2001). This lesser used keora can be used for poles, anchor logs and cross-arms after proper preservative treatment. REB has also included this species in their standard for poles, anchor logs and cross-arms (REB Standard, 2001). For power transmission and electrification, keora wood needs higher retention and penetration with preservative. The present study was conducted to find out the penetration and retention of Keora (Sonneratia apetala) poles treated by full cell method with CCA-C preservative to ensure the efficient and effective use of this huge lesser used timber resource of Bangladesh.

\section{Materials and Methods}

\section{Collection and preparation of the log}

Keora poles were collected from the Sundarbans of Bangladesh having the diameter of $20-22 \mathrm{~cm}$ with the length of 10-12 $\mathrm{m}$. The poles were converted into $1 \mathrm{~m}$ bolts for the preservative treatment. Bark was removed manually and the poles were dried to the moisture content of $15 \%$ for better

\footnotetext{
*Corresponding author. E-mail: nazrul17@yahoo.com
} 
retention and penetration. Cross section of the logs was sealed before treatment with epoxy resin to stop the end penetration of preservative. The average sapwood portion of the pole was $61.6 \%$.

\section{Preservative Treatment}

The keora poles were treated with $5.5 \%$ (w/w basis) CCA-C type preservative by full cell method of wood preservation. The active ingredients were on oxide basis as per AWPA Standard P5 (1996). The initial and final vacuum used throughout the study was 20 and 30 minutes, respectively with the $612 \mathrm{~mm} \mathrm{Hg}$ pressure $(81.6 \mathrm{kPa})$. The treatment pressure was $200 \mathrm{psi}(1,379 \mathrm{kPa})$ for 2, 3, 4 and 5 hours treating durations and the temperature was kept at room temperature (REB Standard, 1998). After completion of the treatment, the poles were stacked for air drying in stack yard for two weeks for fixation of preservatives. The experiment was done at least three times repeatedly.

\section{Determination of preservative penetration and retention}

Specimens for penetration and retention analysis were collected by boring with an increment borer. At least 10 borings were done from each sample. Penetration and retention of preservative was analyzed by AWPA Standard A3-1996 and AWPA Standard A9-1996, respectively. The data was analyzed statistically for their significance.

\section{Results and Discussion}

The penetration of CCA-C type preservative into keora poles was $3.82,4.13,4.2$ and $4.36 \mathrm{~cm}$, respectively for 2, 3, 4 and 5 hours treating duration (Fig. 1). this variation was statistically significant for different treating duration (Table I). From the LSD, it was found that the average penetration of preservative in 2 hours treating duration was significantly lower $(3.82 \mathrm{~cm})$ than the other three treating duration (i.e., 3, 4 and 5 hours) but there was no significant variation among 3, 4 and 5 hours treating duration. The maximum penetration of preservative was found in 5 hours treating duration $(4.36 \mathrm{~cm})$.

Table I: Summaries of analysis of variance of the penetration and retention of preservative in Sonneratia apetala poles

\begin{tabular}{l|c|c}
\hline \multirow{2}{*}{$\begin{array}{l}\text { Source of } \\
\text { variation }\end{array}$} & \multicolumn{2}{|c}{$\begin{array}{c}\text { F-rations and } \\
\text { statistical significance }\end{array}$} \\
\cline { 2 - 3 } & Penetration & Retention \\
\hline Treating duration & $6.685^{*}$ & $64.665^{*}$ \\
\hline
\end{tabular}

Note: $*=$ significant at $95 \%$ probability level, $\mathrm{F}=3.59(3$ and 11 degree of freedom)

It was found that the retention of $\mathrm{CrO}_{3}, \mathrm{CuO}$ and $\mathrm{As}_{2} \mathrm{O}_{5}$ varied on the basis of ratio of constituent present in CCA-C type preservative and also strongly depend on the pressure as well as its duration. The average retention for $\mathrm{CrO}_{3}$ was 4.23 , $5.95,7.62$ and $8.46 \mathrm{~kg} \mathrm{~m}^{-3}$; for $\mathrm{CuO}$ it was $1.78,2.51,3.18$ and $3.56 \mathrm{~kg} \mathrm{~m}^{-3}$ and for $\mathrm{As}_{2} \mathrm{O}_{5}$ it was 3.14, 4.28, 5.55 and $6.29 \mathrm{~kg} \mathrm{~m}^{-3}$, respectively for $2,3,4$ and 5 hours treating duration (Fig. 2).

The total retention of CCA-C preservative was 9.15, 12.72, 16.35 and $18.31 \mathrm{~kg} \mathrm{~m}^{-3}$ respectively for 2, 3, 4 and 5 hours treating duration. The total retention of preservative among

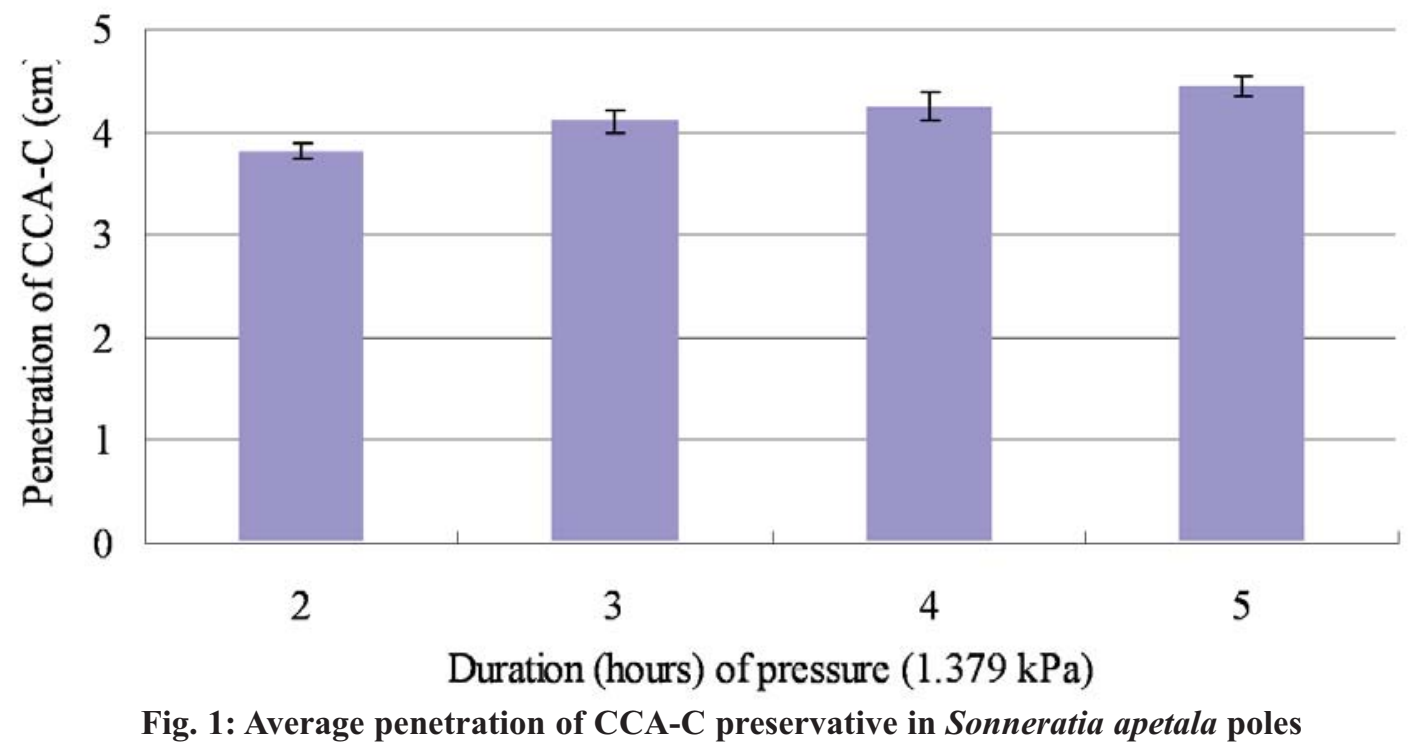

It was observed that penetration of preservative increased with the increase of treating duration. It was also found that different treating duration was significantly varied (Table I). The total retention of preservative was also increased with 


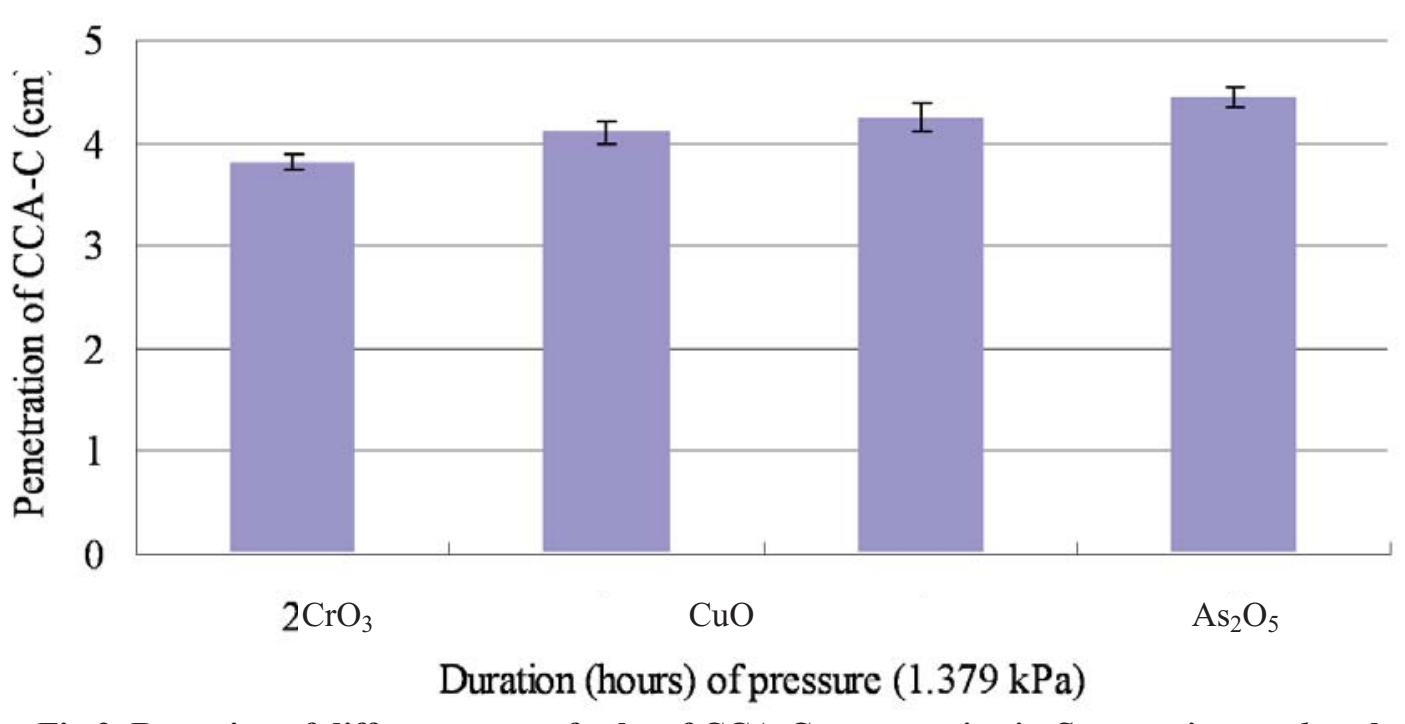

Fig 2. Retention of different types of salts of CCA-C preservative in Sonneratia apetala poles

the increase of treating duration. From the LSD, it was observed that the total retention of CCA-C preservative of $S$. apetala poles in different treating duration (i.e., 2, 3, 4 and 5 hours) significantly varied from each other (Table II). The maximum total retention of preservative was found in 5 hours treating duration $\left(18.31 \mathrm{~kg} \mathrm{~m}^{-3}\right)$ and minimum total retention was in 2 hours treating duration $\left(9.15 \mathrm{~kg} \mathrm{~m}^{-3}\right)$.

Lahiry (2001) graded keora wood to the treatable group and it is in the 20 timber species that have sufficient sapwood or treatable heartwood to meet penetration requirement equivalent to $44 \%$ of radius of the poles. In the present study, the sapwood $(3.84 \mathrm{~cm})$ to heartwood $(2.36 \mathrm{~cm})$ ratio of keora was 1.63:1. According to the result of this study, it is clear that preservative penetrated throughout the sapwood of the keora poles for any treating duration which meets the speci-

Table II: Summaries of multiple comparisons (LSD) test of the penetration and retention of preservative among the different treating duration

\begin{tabular}{l|c|c|c|c}
\hline \multirow{2}{*}{ Properties } & \multicolumn{4}{|c}{ Preservative treatment duration } \\
\cline { 2 - 5 } & 2 hours & 3 hours & 4 hours & 5 hours \\
\hline Penetration & $*$ & $\mathrm{~ns}$ & $\mathrm{~ns}$ & $\mathrm{~ns}$ \\
Retention & $*$ & $*$ & $*$ & $*$ \\
\hline
\end{tabular}

Note: $*=$ significant at $95 \%$ probability level, ns $=$ not significant at $95 \%$ probability level.

fications of Bangladesh Standard on code of practice of wood preservation (BDS, 1978). Yunus-uzzaman and Akhter (1999) stated that an average penetration of $2.97 \mathrm{~cm}$ was achieved with $100 \mathrm{psi}(689.5 \mathrm{kPa})$ pressure for 3 hours treating duration in eucalyptus poles by oil-born preservative. It was found that in any treating condition, the penetration of
CCA-C preservative was $100 \%$ in the sapwood zone. Therefore, it can be concluded that sapwood of keora poles is possible to treat by pressure process.

Retention varied in small scale for different types of poles treated in different treating condition. It is thought that retention is influenced by the level of pressure, its duration and the preservation process. Wood treated with 200 psi pressure $(1,379 \mathrm{kPa})$ for 6 hours retained the highest amount of CCA$\mathrm{C}$ preservative and it was $20 \mathrm{~kg} \mathrm{~m}^{-3}$ or $4 \% \mathrm{w} / \mathrm{w}$ dry oxide basis as per the Rural Electrification Board (REB) standard. In the study, the highest retention was $18.31 \mathrm{~kg} \mathrm{~m}^{-3}$ when the keora wood was treated with 200 psi pressure $(1,379 \mathrm{kPa})$ for 5 hours. The lowest was $9.15 \mathrm{~kg} \mathrm{~m}^{-3}$ when the keora wood was treated at this pressure for 2 hours. Hence, the retention of preservative in 5 hours treating duration can be considered adequate for Keora poles and it can be used in power transmission lines in Bangladesh.

\section{Conclusion}

The timber uses of Keora wood are very limited except some minor constructions, fuel wood and environmental protection purposes. It is a medium dense and moderately strong timber but naturally non-durable. So, preservative treatment with suitable preservative can increase its timber quality and serviceability. Preservative treatment by full cell process with CCA-C preservative possesses satisfactory performance. The penetration of preservative in $S$. apetala poles was highly satisfactory and gave the desire level of preservative retention. The study revealed that a significant higher penetration of $4.36 \mathrm{~cm}$ with the retention of $18.31 \mathrm{~kg} \mathrm{~m}^{-3}$ has been achieved in 5 hours treating duration at 200 psi pressure $(1,379 \mathrm{kPa})$. Thus, the CCA-C treated Keora wood can be 
used satisfactorily as poles, posts, anchor logs and cross arms to meet the demand of Rural Electrification Board (REB) in Bangladesh.

\section{Acknowledgement}

The authors are thankful to the Nordic Woods Ltd. Khulna, Bangladesh and Rural Electrification Board (REB), Dhaka, Bangladesh for their cordial assistance in carrying out the preservative treatment and for giving opportunities to use their laboratory for various tests.

\section{References}

AWPA Standard A3 (1996). Standard method for determining penetration of preservative and fire retardants. In: American Wood Preservers' Association (AWPA) Book of Standards, Granbury, TX.

AWPA Standard A9 (1996). Standard Method for analysis of treated wood and treating solution by chemical analysis method. In: American Wood Preservers' Association (AWPA) Book of Standards, Granbury, TX.

AWPA Standard P5 (1996). Standard for water-borne preservative. In: American Wood Preservers' Association (AWPA) Book of Standards, Granbury, TX.

Baksha M. W. and Islam M. R. (1999). Infestation intensity of Zeuzera conferta Walker (Cossidiae: Lepidoptera) in Sonneratia apetala plantations in Bangladesh. Bangladesh Journal of Forest Science 28(1): 1-6.

Bangladesh Standards (BDS) (1978). Code of practice for preservation of timber. Bangladesh Standards and Testing Institution, BDS 819:1975, Dhaka. 36pp.

Das S. and Siddiqi N. A. (1985). The mangroves and mangroves forests of Bangladesh. Mangrove Silviculture Division, Bulletin 2, Bangladesh Forest Research Institute, Chittagong, pp.141-142.

Haque A. K. F., Alam M. R., Kabir M. E. and Islam M. S. (1999). Effect of salinity on the germination of Sonneratia apetala Butch-Ham. Bangladesh Journal of Forest Science, 28(1): 32-37.

Khaleque M. A. and Hannan M. O. (1993). Machine and hand tool properties of five mangrove species. Wood Working Series, Bulletin 8, Bangladesh Forest Research Institute, Chittagong, 7pp.

Lahiry A. K. (2001). Applied wood preservation. Magnum Opus, Dhaka, Bangladesh, 416pp.

Lakshmanan K. K., Rajendran J. and Ravignanam T. (1984). Importance of mangroves - raw material function and the role in environment. Indian Journal of Forestry, 7(3): 201-207.

Latif M. A. and Yunus-uzzaman . De B.C. (1981). Pressure treatment of Sundri poles with oil-borne preservative. Bano Biggyan Patrika 10(1\&2): 41-48.

Latif M. A., Yunus-uzzaman M. and De B.C. (1982). Pressure treatment of Teak poles with oil-borne preservative. Bano Biggyan Patrika 11(1\&2): 22-32.

Leightley E. L. (1987). Soft rot decay in copper chromo arsenate treated Eucalyptus. Department of Forest, Queensland, Australia.

REB Standard (1998). REB standard for wood poles. Pub No. 460-1988, Revision 10, April 1998, Rural Electrification Board, Dhaka, 46pp.

REB Standard (2001). REB Standard for Wood Poles. Pub No. 460-1988, Revision 11, May 2001, REB Dhaka, 46pp.

Sattar M. A. and Bhattacharjee D. K. (1983). Strength properties of S. apetala (Sonneratia apetala). Timber Physics Series, Bulletin 7, Bangladesh Forest Research Institute, Chittagong, 6pp.

Siddiqi N. A. (1999). Status and conservation of mangrove in the Indian Sub Continent. Symposium on Mangrove and Mangrove Ecosystem, September 7, 1999, Bali, Indonesia, $11 \mathrm{pp}$.

Siddiqi N. A. (2001). Mangrove forestry in Bangladesh. Institute of Forestry and Environmental Sciences, University of Chittagong, Chaittagong, Bangladesh, 98-99 pp.

Siddiqi N. A. and Shahjalal M. A. (1997). Feasibility of under planting in the mangrove plantations along the eastern part of Bangladesh. Bangladesh Journal of Forest Science, 26(1): 76-78.

Tamblyn N. E. (1984). Preservation and preserved wood. In: Hillis, W.E and Brown, A.G. (eds.) Eucalyptus for Wood Production. Academic Press, CSIRO, Australia, 56-57pp.

Yunus-uzzaman M. and Akhter, K. (1999) Pressure treatment of Eucalyptus camaldulensis poles with oil-borne preservative. Bangladesh Journal of Forest Science, 28(1): 47-53.

Received: March, 02, 2011;

Accepted : April 25, 2011 